\title{
Critical Criminology as Academic Activism: On Praxis and Pedagogy, Resistance and Revolution
}

\author{
Bruce A. Arrigo ${ }^{1}$
}

Published online: 23 July 2016

(C) Springer Science+Business Media Dordrecht 2016

Critical Criminology (CC) holds itself out as an inclusive voice and a radical outlet for activism. This Special Issue examines the status of academic activism through an eclectic set of criminological voices. Dr. Joanne Belknap's Presidential Address (2015) draws attention to the question of criminological activism and challenges critical academics of various stripes to reflect on the same. This is activism that extends to, reaches within, and goes beyond the orthodoxy of "ivory tower" instruction, research, and service. The purpose of this Special Issue, then, is to examine how the question of academic activism for radical legal change and critical social justice has been (and continues to be) addressed by several CC scholars and practitioners. These are academic activists whose critical work in criminology seeks to politically overcome and structurally change the relations of humanness (Arrigo 2015) that marginalize dissent, territorialize knowledge, and/or homogenize identity around the globe.

Organizationally and conceptually, how does this Special Issue accomplish its objective? Four change-oriented themes are featured and probed within the assembled articles. These are general themes whose central purpose is to link the question of academic activism to its everyday, communal, worldwide, and/or environmental struggles for justice. These themes include: the (trans)praxis of academic activism, the pedagogy of academic activism, the restorative experiences and/or moments of activist resistance, and the transformative properties of revolutionary change. These four themes constitute the subtext of this Special Issue on academic activism and critical criminology.

Strategically and pragmatically, how do the authors help this Special Issue realize its stated objective? In the first article, Matt Ball explores the existing and possible future connections between queer criminology and academic activism. He illuminates the manner in which queer politics developed out of activism, emphasizing several intersectional points within criminal justice and through crime control. Ball concludes his analysis by

Bruce A. Arrigo

barrigo@uncc.edu

1 University of North Carolina, Charlotte, NC, USA 
proposing a number of directions for growing the relevance and standing of queer criminological activism within the academy. Such directions are necessary, he argues, if Belknap's call for radical legal change and critical social justice are to follow. In the second article, Jeff Ross, Rick Jones, Mike Lenza, and Steve Richards delineate the ways in which Convict Criminology has been an outlet for critical policy reform within and outside the academy for nearly two decades. The authors explain how Convict Criminology represents an inclusive school of criminological thought, functions as a radical social movement and organization, and serves as an international forum for a diverse membership of educated convicts, ex-cons, and non-cons. In this way, the authors provide an historical account of Convict Criminology that clarifies its activist roots and specifies its progressive agenda. In the third article, David Rodríguez Goyes examines several advocacy issues linked to green criminology. Specifically, Goyes responds to assertions that activism (as environmental justice) and the production of knowledge (as science) must never be joined for fear of political bias and cultural economics. Goyes utilizes examples from Latin America to defend and develop his activist thesis. In the fourth article, Ron Kramer proposes an academic activism that responds to the ravages of state violence and/ or crime. Kramer makes a case for a public criminology whose instructional message (and voice) comes from within the prophetic tradition. He identifies three strategies consistent with this tradition. They consist of deconstructing the cultures of denial and normalization; challenging empire, including corporate capitalist power; and working to build the international political community. In the fifth article, Andreas Aresti and Sacha Darke identify and explore examples of British Convict Criminology that are taking place in Europe. They are keen to highlight the importance of collaborative research-activist projects. In so doing, the authors help explain the integral group role occupied by non-con academics on behalf of Convict Criminology's activism. In our sixth and final full-length article, Bruce Arrigo and Heather Bersot explore the pedagogy of justice for a people yet to be. They argue that revolutionizing criminological activism requires reliance on a philosophy of change or of "tranxpraxis." The authors define this philosophy as the dialogical and relational pedagogy of mutual struggle, of shared being/becoming. Arrigo and Bersot specify the coordinates of transpraxis as theory, explain how revolutionary activism necessitates a critical pedagogy for a people yet to be, and they reconceive the educational terrain of criminological activism as the pedagogy of becoming. Arrigo and Bersot conclude by specifying how the transpraxis properties of their proposed pedagogy facilitates revolutionary academic activism and furthers the radical potential of transformative justice.

This Special Issue on academic activism also includes a Response Essay from Joanne Belknap and a book review from Cheryl Peace. The Response Essay critiques the assembled articles; the book review comments on Hillary Potters' recent work, Intersectional Criminology. The essay and review further remind us of CC's vitality whose fundamental intention is to further legal change and social justice through purposeful forms of academic activism.

Finally, it is worth noting that this edition of Critical Criminology could never have been completed without the generous assistance and/or support of several individuals. I want to thank Jeff Ross and David Kauzlarich for asking me to serve as Issue Guest Editor. Very early on, they saw the potential in this project. I also am indebted to Adam Duso. He worked tirelessly as Managing Editor, ensuring that all manuscripts systematically underwent peer review, and that the set of articles seamlessly moved through the production pipeline. I also want to acknowledge our international cast of peer reviewers. Their unique insights and attention to detail helped to make each manuscript better, more perfect. Of course, all of the article contributors warrant recognition. In a very real sense, writing 
about academic activism as a critical criminologist is a tangible expression (an embodiment) of living the struggle for justice. Indeed, this $i s$ the change-directed work of praxis and pedagogy, resistance and revolution.

Namaste!

\section{References}

Arrigo, B. A. (2015). Responding to crime: Psychological jurisprudence, normative philosophy and transdesistance theory. Criminal Justice and Behavior: An International Journal, 42(1), 7-18.

Belknap, J. (2015). Presidential address: Activist criminology: Criminologists' responsibility to advocate for social and legal justice. Criminology, 53(1), 1-22. 